\title{
Daniel Kalla: storytelling, pure and simple
}

A $s$ the author of medically themed novels, physician Daniel Kalla pushes his characters into dramatic, ethical dilemmas. Consider Kalla's newest book, Rising Sun, Falling Shadow (HarperCollins Canada), set in Japanese-occupied Shanghai, China, during World War II. The hero of the story, Dr. Franz Adler, is a surgeon at a hospital for Jewish refugees. One day, he is forced to treat a grievously wounded senior Japanese officer who is plotting to eliminate Shanghai's 20000 Jewish refugees. Dr. Adler can save the officer and risk the lives of the refugees, or let the officer die and potentially save the lives of the refugees.

What should the doctor do? What would you do? These ethical dilemmas are faced not only by Kalla's characters but vicariously by all those who read his novels and wonder how they, as medical professionals, would treat wartime enemies.

Rising Sun, Falling Shadow is Kalla's eighth medically themed novel and a sequel to The Far Side of the Sky, which was described by The National Post as "storytelling pure and simple." Kalla is currently writing a third novel about Dr. Adler, a Jewish-Austrian refugee similar in many ways to Kalla's own late physician father, Frank. Once this novel is complete, Kalla will likely return to writing another contemporary medical thriller, like Pandemic, the novel that started his writing career in 2005. There has been, on average, a book a year since. Titles include Rage Therapy, Blood Lies and Cold Plague.

Pandemic tapped into 2 of the Western world's great anxieties by creating a deadly SARS-like virus intentionally spread by suicidal Muslim terrorists. The book has been translated into a dozen languages, with more than 200000 copies sold worldwide. Sales of his subsequent books have been slower but strong enough to keep him enthusiastically writing.

Kalla is the director of the emergency department at St. Paul's Hospital in downtown Vancouver, British Columbia. Emergency physicians are, like the fictional Dr. Adler, faced with ethical dilemmas daily, although the issues are less dramatic than those

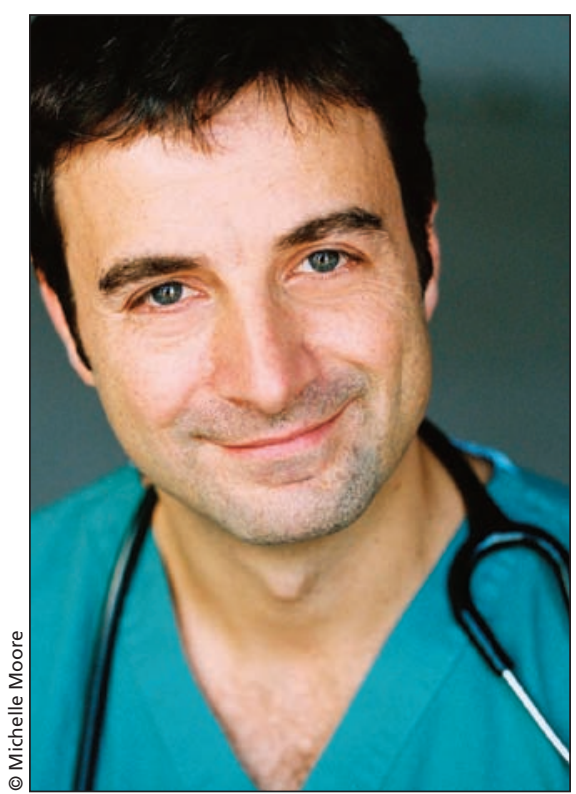

The writing bug has stuck with Daniel Kalla despite his self-confessed short attention span.

encountered during wartime. St. Paul's patients include many drug addicts. Physicians must frequently decide who really needs narcotics and who is just hoping to get high. And, of course, physicians at all overcrowded emergency departments must constantly prioritize patients' illnesses. "Who gets the last bed?" asks Kalla. The man with the serious chest pains? The woman with the broken hip? Or someone else altogether?

Surely, Kalla was destined to be a doctor. "I come from this medical dynasty," he says. His father and grandfather both survived the Holocaust to become doctors in Canada. His wife is a pediatrician, and now the elder of their 2 teenaged daughters is showing interest in cardiology.

After medical school, Kalla's childhood dream to become a writer persisted. While still in his mid-20s, the newly minted doctor took a screenwriting course at Simon Fraser University in Burnaby, BC, in 1998. Kalla's teacher was impressed; the new writer's confidence was boosted: "I really got the bug."

That bug stuck with Kalla, despite his self-confessed short attention span, a quality he claims is perfect for an emergency physician forced to rush from one crisis to another. Long hours of writing, however, are like a tonic; they reinvigorate Kalla for his hospital shifts.

By 2003, Kalla was on the front lines screening possible SARS cases in Vancouver. "What if this is not random but somebody is deliberately doing it?" Kalla thought. "I wouldn't say it was a eureka moment, but the thought stuck in my mind, and I began to think this would be an interesting idea for a thriller, with suicide bombers actually spreading infections around to further some geopolitical agenda."

Kalla's American publisher, Forge Books, loved the story but initially balked at the title Pandemic. "Nobody knows what a 'pandemic' is," came the complaint. Then fate intervened. "The New York Times ran a cover story about bird flu, 'The Next Pandemic,' a month before my book came out." It was like a free advertisement. Sales soared.

Despite being a full-time doctor, Kalla also seems to be a full-time writer. Crafting novels is just the beginning of the author experience. There are also the publicity interviews and the monthly appearances by Skype at book clubs. He also maintains an informative blog on the writerly life on his website 
(www.danielkalla.com). One recent blog entry explains how he manages his time.

My advantage is my drive. When I sink my teeth into something, I do so with singlemindedness that borders on obsession. Other obligations and commitments invariably suffer, but I try to follow one rule that I won't let my wife or kids bear the brunt of my obsession. Family still comes first. However, when I'm writing a new novel, I cut back on all other pastimes. Netflix loses an avid follower. My timing in tennis goes to crap. I even stop reading for pleasure and focus solely on research.

Kalla says he is not as alarmist about pandemics in real life as he is in his books. Yes, a deadly crisis like the Spanish flu in 1918 could return and kill thousands, but those are rare occurrences. Kalla's fears for humanity are more exemplified by his second book, Resistance, in which a deadly bacterium is immune to all antibiotics. ("The kind of magnetic story you can't put down," declared Vancouver newspaper The Province.)

"The issue of the story - antibiotic resistance - still terrifies me," says Kalla. "I still think there will come a time when antibiotics won't work anymore. From my perspective, if I had to choose the one great threat, I would choose that."
But Kalla is not obsessing about plagues these days, not with a third Shanghai story to complete. "There are not many upbeat Holocaust stories, but this is one," says Kalla. Ninety percent of Shanghai's Jewish refugees survived. Their odds for survival exceeded those of Jews who remained in Europe. Maybe someone like the fictional Dr. Franz Adler improved those odds by his handling of life-and-death ethical dilemmas.

Paul Gessell

Art critic

Chelsea, Que.

CMAJ 2014. DOI:10.1503/cmaj.131413

\section{The dude abides}

\author{
Dude, Where's My Stethoscope? \\ and Other Stories from the ER \\ Donovan Gray \\ Elysium Books, 2012.
}

$\mathrm{H}$ ow hilarious is medicine? It's hard to say for certain. As a medical student, I learned how easy it was to become overwhelmed by the absurdity of a situation and default to amusement. "Gee, these suction cups that are supposed to hold ECG leads to a patient's chest make an odd little noise when they keep popping off." It's pretty funny at $3 \mathrm{am}$. Except that it's also frustrating and frightening and probably not at all funny for the patient.

The truth, which Dr. Donovan Gray acknowledges in this memoir, is that humour is often a defence against the anxiety and angst that arise in the practice of medicine. Gray has worked for many years in family practice and emergency medicine, and during that time he has collected a wide variety of experiences which he relates in over 90 short, interconnected essays as he

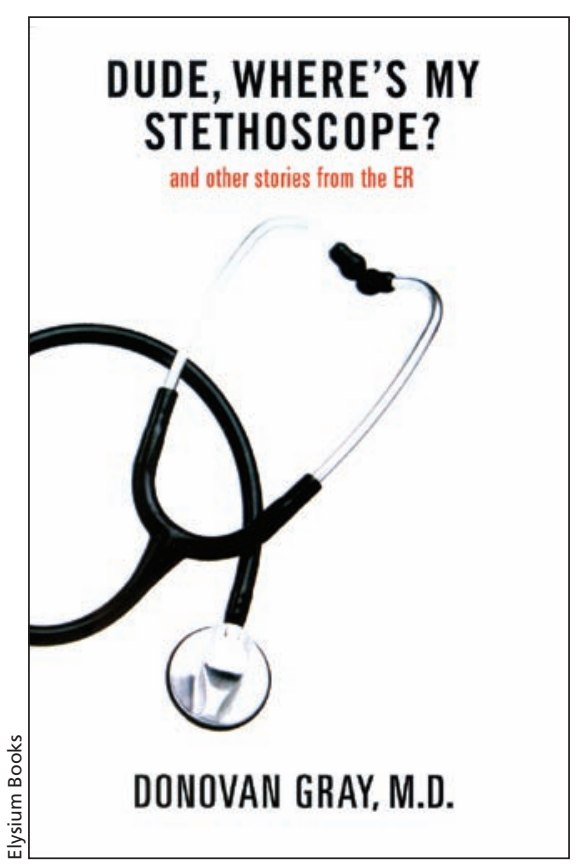

tells the story of his life in practice. Through the tales he tells, a picture emerges of what it means to practise in a busy emergency room in Canada, with all its unexpected frustrations and rewards.

I thought most of the anecdotes in the book were funny; very funny, in fact. One gets the impression that they are also true, which raises questions about confidentiality that every physician who writes about patients must address in some way. In Dude, Where's My Stethoscope, there is the additional complication that most of the time, the patients are the butt of the joke. As someone who has dabbled in medical humor writing, I find it is a fine line to walk between funny and making fun. At times, Gray is perilously close to crossing the line.

As I read Dude, I found myself wishing that Gray would apply his considerable talents as a writer to a more balanced style that incorporates humour into a nuanced and reflective narrative. While many physicians will find this an amusing book, I feel that there is so much more that we could learn from his experiences if we weren't so quick to laugh them off.

\section{Lara Hazelton MD}

Psychiatrist

Halifax, NS

CMAJ 2014. DOI:10.1503/cmaj.130867 